\title{
Comparative Analysis of Economic Growth in Nigeria and Kenya: A Fractional Integration Approach.
}

\author{
Olushina Olawale Awe ${ }^{\mathrm{a}}$, Robert Mudida ${ }^{\mathrm{b}}$ and Luis Alberiko Gil-Alana, ${ }^{\mathrm{c}}$ \\ ${ }^{a}$ Department of Mathematical Sciences, Anchor University, Lagos, Nigeria \\ oawe@aul.edu.ng \\ ${ }^{\mathrm{b}}$ Strathmore Business School, Strathmore University, Nairobi, Kenya. \\ rmudida@strathmore.edu \\ ${ }^{c}$ Department of Economics and NCID (ICS), University of Navarra, Pamplona, Spain \\ alana@unav.es
}

\begin{abstract}
:
This paper is a comparative analysis of Nigeria and Kenya, the largest economies in West and East Africa respectively, on the basis of the time series properties of their economic activities through the Gross Domestic Product (GDP) and growth rate series. It further analyses how differing policy and political economy processes contributed to the two countries' economic growth trajectories despite becoming independent republics at almost the same time. We study the two economies using a long-memory-fractionally integrated approach. The results show a high degree of persistence in both cases. When non-linearities are taken into account, evidence of mean reversion is found in the GDP series in the two countries. This is indicative of how the two countries in very distinct African contexts followed broadly different but, in some ways, similar paths toward economic growth since independence.
\end{abstract}

JEL Classification: C22, C59, Y10

Keywords: Economic growth; long memory, fractional integration, GDP, Kenya, Nigeria.

Corresponding author: Prof. Luis A. Gil-Alana

University of Navarra

Faculty of Economics and NCID

Edificio Amigos

E-31009 Pamplona

Spain

Email: alana@unav.es

*: Prof. Luis A. Gil-Alana gratefully acknowledges financial support from the Ministerio de Economía y Competitividad (ECO2017-85503-R). 


\section{Introduction}

This paper concerns the comparative time series analysis of the economic growth in Nigeria and Kenya by examining their statistical properties, and also investigating what factors may explain the erratic growth rates observed over the past 55 years of independence in both countries. Nigeria attained independence in 1960, became a republic in 1963 and soon after in 1966, was engulfed in political turmoil that ushered in a regime of coups, regime changes, political instability that eventually led to a civil war between 1967 and 1970. The inefficiency of government operations soon became a major bottleneck to the growth and development of the Nigerian economy leading to a long period of economic volatility. This scenario generated intense pressure on the government from within and outside the country to undertake economic reforms for the purpose of encouraging growth and development (Edo, 2002).

The initial response of government to the economic stagnation was to put in place a number of stabilization measures as reflected in the Economic Stabilization Act of 1982. The measures and controls were, however, ineffective to the extent that the growth rate of Gross Domestic Product (GDP) turned negative in the early and late 1980s when (see Figure 1) capacity utilization in industries declined drastically (Akinkumi, 2017). In 1985 more stringent fiscal, monetary and exchange control measures, as well as the incomes policy, were designed to arrest the deteriorating economic situation. Although the new approach helped to re-establish some control over the economy, the problem of macroeconomic imbalance however remained unresolved. Fundamental economic reform was therefore seen as the only viable option that could prevent the total collapse of the Nigerian economy (Edo, 1995; 2002). This consideration informed the IMF/World Bank inspired Structural Adjustment Program (SAP), which took effect in 1986 and ushered in the era 
of social economic reforms that have tended to create a more conducive environment for economic growth and development (Agu and Evoh, 2011; Awe, et al., 2015).

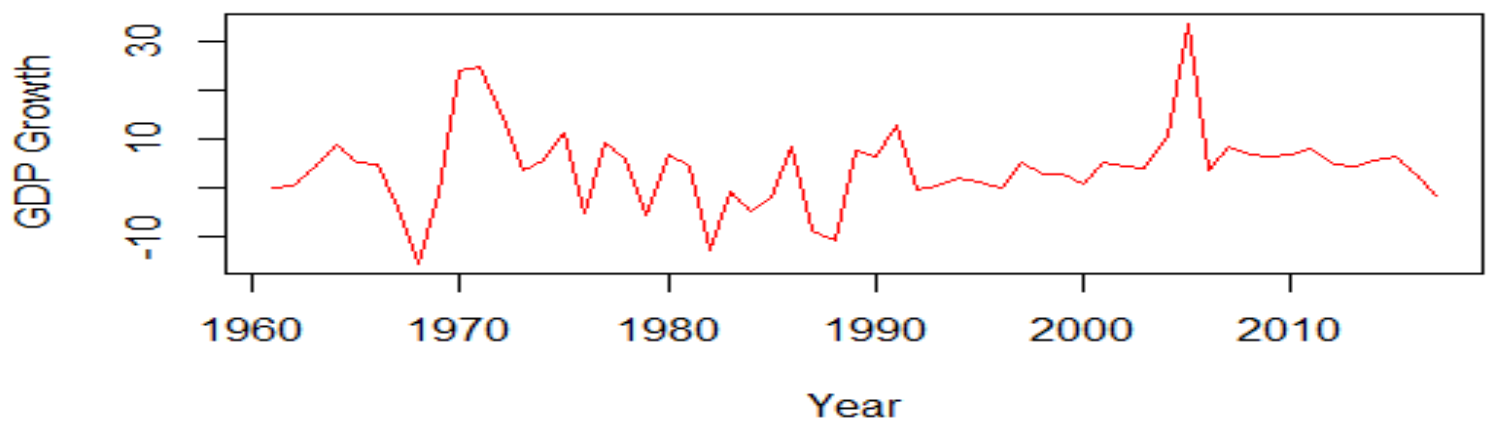

Figure 1: Nigeria's GDP annual growth rate.

The various reforms and policies that have been put in place since 1986 have contributed in no small measure to the turn-around of the Nigerian economy in terms of its growth rate, and the economy began to pick up from the late 1980s (Figure 1) until it suffered a dramatic recession in 2016. Nigeria is currently ranked as the largest economy in Africa, with a large and viable capital market as well as a rapidly growing population. As a regional power, and the largest economy in West Africa (although it suffered a recession in 2016), the Nigerian economy represents about 55 percent of West Africa's GDP and accounts for 64 percent of GDP based on purchasing power parity (PPP) valuation of the fifteen member countries in the ECOWAS subregion. Nigeria has a population of about 170 million people and it has huge potential which is reflected in its natural resources which include about 80 million hectares of arable land, 33 solid minerals, large oil and gas reserves ranking it the twelfth largest oil producer and eighth largest gas producer in the world (Akinkunmi, 2017). It is regarded as a middle income mixed economy and emerging market with expanding financial, telecommunications and entertainment sectors 
(Awe, et. al, 2015). It is primarily product oriented and dominated by agriculture and crude oil production. The oil and gas sector is the main driver of the economy and it accounts for above 96 percent of total exports, 95 percent of foreign exchange earnings and about 80 percent of budgetary revenues. In 2011, the petroleum sector accounted for 79 percent of federal revenues and 71 percent of export revenue. The sector's contribution to GDP was 14.7 percent in 2011 and 12.9 percent in the second quarter of 2013 (Awe, et. al, 2018).

Like Nigeria, Kenya's post-independence economic growth has been characterized by ups and downs since it witnessed a relative collapse after a period of steady growth that lasted from independence in 1963 until 1974. The strong economic performance of the 1960s and early 1970s was not sustained in the decades thereafter with the Kenyan economy being adversely affected by the OPEC oil price shocks of the 1970s, the global debt crisis of the 1980s and the instability associated with the political transformation of the 1990s. The development of a highly centralised state after independence was also associated with the entrenchment of extractive institutions in the decades after independence. More inclusive institutions are only more recently being developed with the inauguration of a new devolved constitution in 2010. (Mudida, 2015) Although the performance of the Kenyan economy has improved since 2008, it remains characterised by low savings accompanied by poor domestic capital formation, increasing only marginally from $19.4 \%$ in 2007 to $20.1 \%$ in 2011 (Republic of Kenya, 2012). Kenya is currently classified as a lower middle income country by the World Bank, having a GDP per capita in nominal terms of 1300 US dollars. Its real GDP growth rate has also been lower than many other African countries, including countries in the East African Community (Gil-Alana and Mudida, 2018).

The following plot in Figure 2 summarizes growth in Kenya which has been very volatile, especially during the first twenty years of independence. 


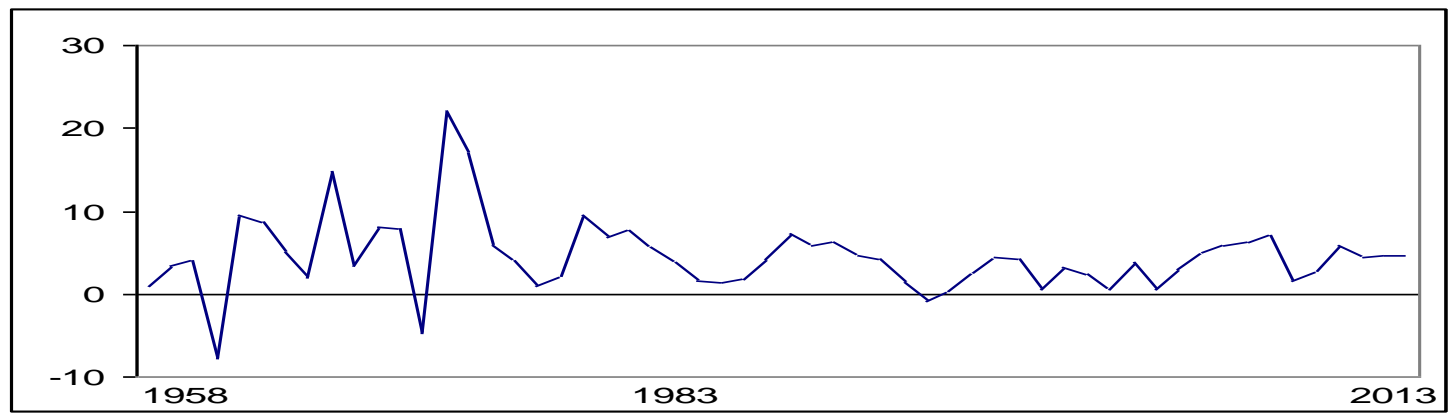

Figure 2: Kenya's GDP annual growth rate.

In addition to being erratic, economic growth in Kenya has long been unbalanced, predominantly driven by domestic consumption, which accounts for about 78 percent of GDP. Investment remains well below what is needed to deliver sustained high growth rates. Capital formation in Kenya during the 2000s only averages 18.1 percent of GDP. In fact, while Kenya had one of the highest investment rates among peer countries in the 1980s, this declined steadily in the next two decades to the point that Kenya had the lowest levels of capital formation of all its peers during the 2000s (Farole and Mukim, 2013). Manufacturing contribution to GDP has stagnated for several decades although Kenya has developed vibrant non-traditional exports in horticulture and remains a leading tourist destination in the world. Kenya's growth is also periodically affected by elections with the 2007 elections having had an extremely adverse effect on growth having been associated with post-election violence. The effects of post-election uncertainty on Kenyan growth have also most recently been evidenced in the 2017 elections when the Kenyan economy expanded by $4.9 \%$ in 2017 compared to $5.9 \%$ in 2016 . This slow growth was partly because of the uncertainty associated with the long electioneering period accompanied by adverse weather conditions. These adverse weather conditions also periodically affect Kenyan economic growth as the agricultural sector constitutes about 25\% of Gross Domestic Product (Republic of Kenya, 2018). 
The Kenyan economy also has a large informal sector which mainly takes the form of small unregistered firms and street vendors. In Kenya, the informal sector is estimated at $34.3 \%$ and accounts for about $77 \%$ of employment (Institute of Economic Affairs, 2012). A total of 897.8 thousand new jobs were created in 2017 with 787.8 thousand of those jobs being created in the informal sector. Employment in the informal sector accounted for 83.4 per cent of total employment in 2017 (Republic of Kenya, 2018). Although formal jobs in Kenya are in higher productivity and growth sectors, the formal sector has low job creation capacity leading many jobseeking individuals to work in the more unstable and lower productivity informal sector. Key subsectors in the informal sector include trade, hospitality and manufacturing (World Bank, 2016). The informal sector's more volatile unemployment compared to the formal sector and its large contribution to the economy and job creation also in part explains the erratic nature of Kenyan economic growth (Mendi and Mudida, 2018).

The aim of this work is to carry out a comparative analysis of the two largest economies in West and East Africa respectively in terms of their economic growth series from 1960 to 2017 inclusive and to make recommendations based on the analyses on what each country should do to strengthen economic growth. In addition, the comparison is interesting because Kenya is largely an oil-importing economy (although modest commercial reserves have recently been discovered but are yet to be commercialised), while Nigeria is one of the largest oil exporters in the world. Sectoral drivers of economic growth therefore differ considerably between the two economies and this provides for an interesting analysis.

The outline of this paper is as follows: Section 2 is devoted to the methodology used in the paper that includes concepts such as long memory and fractional integration. Section 3 describes the data and the main empirical results for the Nigerian economy, while Section 4 discusses the 
results and compares them with those in Kenya, recently investigated in Gil-Alana and Mudida (2018). Section 5 concludes the paper.

\section{Methodology}

In the paper we use a methodology based on the concepts of long memory and fractional integration. Long memory is a very wide class of models which is characterized by the spectral density being unbounded at one or more frequencies in the spectrum, and it is so-called because of the strong degree of association between observations which are very much related even if they are very distant from each other. A very common class of models within this category is the fractionally integrated one, which may be described as integrated of order d, and denoted as I(d) if it can be represented as

$$
(1-L)^{d} x_{t}=u_{t}, \quad t=0, \pm 1, \ldots
$$

with $\mathrm{x}_{\mathrm{t}}=0$ for $\mathrm{t} \leq 0$, and $\mathrm{d}>0$, where $L$ is the lag-operator $\left(L x_{t}=x_{t-1}\right)$ and $u_{t}$ is $\mathrm{I}(0)$ defined, for the purpose of the present work, as a covariance stationary process with spectral density function that is positive and finite. In the case where the parameter $d$ is not an integer, the polynomial in the left hand side in (1) can be expanded in terms of its Binomial expansion, such that, for all real d:

$$
(1-\mathrm{L})^{\mathrm{d}}=\sum_{\mathrm{j}=0}^{\infty} \psi_{\mathrm{j}} \mathrm{L}^{\mathrm{j}}=\sum_{\mathrm{j}=0}^{\infty}\left(\begin{array}{l}
\mathrm{d} \\
\mathrm{j}
\end{array}\right)(-1)^{\mathrm{j}} \mathrm{L}^{\mathrm{j}}=1-\mathrm{d} \mathrm{L}+\frac{\mathrm{d}(\mathrm{d}-1)}{2} \mathrm{~L}^{2}-\ldots
$$

and thus

$$
(1-L)^{d} x_{t}=x_{t}-d x_{t-1}+\frac{d(d-1)}{2} x_{t-2}-\ldots
$$


In this context, d plays a crucial role as an indicator of the degree of dependence in the series. Thus, the higher the value of $\mathrm{d}$, the higher the level of association is between the observations.

These processes, originally proposed in the 80s by Granger (1980, 1981), Granger and Joyeux (1980) and Hosking (1981) garnered popularity fifteen years later when its use was generalized in the analysis of macroeconomic and financial data (see, e.g. Baillie, 1996; Gil-Alana and Robinson, 1997; Michelacci and Zaffaroni, 2000, Mayoral, 2006; Gil-Alana and Moreno, 2012; Abbritti et al., 2016; etc.). The main advantage of this model is that it is more general than the standard methods employed in the literature, in the sense that it includes the standard cases of stationarity $\mathrm{I}(0)$ and nonstationarity $\mathrm{I}(1)$ as particular cases of interest when $\mathrm{d}$ is equal to 0 and 1 respectively. Moreover, this is a very flexible approach that permits us to consider nonstationary persistence though mean reverting processes if the differencing parameter is in the range $[0.5,1)$. In this context, the longer the value of $\mathrm{d}$ is, the longer the time the series to be recovered will be, while if $\mathrm{d}$ is equal to or higher than 1 shocks will have a permanent nature and strong measures will have to be adopted to recover the original trends. ${ }^{1}$

\section{Data Analyses and Results}

Data from Nigeria were obtained from the website of the World Development Index (https://data.worldbank.org/products/wdi). It comprises of data on Gross Domestic Product (GDP) local currency unit series (GDP (current LCU), GDP (current US\$), GDP (constant LCU), GDP per capita (LCU), GDP per capita (US\$)) from 1960 to 2017.

\footnotetext{
${ }^{1}$ See Gil-Alana and Hualde (2009) for a review of fractional integration and cointegration and their applications in economic time series.
} 
The data used in this paper for Kenya correspond to the annual real economic growth series between 1958 and 2013 obtained from the Kenya National Bureau of Statistics. Whereas we use 56 observations which may appear as a small number in order to conduct a time series analysis, it might be sufficient in the context of long memory with annual data, and the results presented across this section seem to be robust across the different specifications.

We start by considering the following model,

$$
y_{t}=\alpha+\beta t+x_{t}, \quad(1-B)^{d} x_{t}=u_{t}, \quad t=1,2, \ldots
$$

where $y_{t}$ refers to each of the series of interest (in our case, GDP and GDP per capita for the Nigerian economy); $\alpha$ and $\beta$ are the coefficients corresponding to an intercept and a linear time trend, and $x_{t}$ that is supposed to be $\mathrm{I}(\mathrm{d})$, where $\mathrm{d}$ is estimated from the data along with the other parameters of the model.

Across Tables $1-4$ we display the estimates of $d$ (and their corresponding $95 \%$ confidence intervals) for the five series examined, considering for each case three potential set-ups: i) the case of no deterministic terms (i.e., $\alpha=\beta=0$ a priori in (2)), ii) a model with an intercept (i.e., $\alpha$ unknown and $\beta=0$ a priori), and iii) a model with an intercept and a linear time trend (both, $\alpha$ and $\beta$ unknown). Tables 1 and 2 refers to the case of uncorrelated errors, while in Tables 3 and 4 we suppose $u_{t}$ in (2) is autocorrelated. For this latter case, we use a non-parametric approach that is based on the exponential spectral model of Bloomfield (1973) that approximates ARMA models with a reduced number of parameters.

\section{[Insert Tables 1 and 2 about here]}

Starting with the case of uncorrelated errors, we observe in Table 1 first that the time trend is required in all except one series (GDP per capita at constant LCU) and the estimated values of 
$\mathrm{d}$ are above 1 in all cases. In fact, the unit root null hypothesis $(d=1)$ is slightly rejected in favour of $\mathrm{d}>1$ for GDP and GDP per capita constant LCU; however, for the remaining three series, this hypothesis cannot statistically be rejected. Table 2 displays, along with the estimates of $\mathrm{d}$ in the selected model for each series, the intercept and the time trend coefficients. We observe that the highest trend refers to GDP current LCU, while it is insignificant for GDP per capita at constant LCU.

\section{[Insert Tables 3 and 4 about here]}

If we permit weak autocorrelation throughout the model of Bloomfield (1973) for the error term, we observe that the estimated values of $\mathrm{d}$ are slightly smaller than before though still significantly large, and the unit root null hypothesis cannot be rejected in any single case. For the GDP per capita at current USD the time trend is now statistically insignificant.

As a final remark, we also conduct a non-linear model, replacing the first equation in (2) by the Chebychev's non-linear polynomials in time, i.e.,

$$
y_{t}=\sum_{i=0}^{m} \theta_{i} P_{i T}(t)+x_{t}, \quad(1-L)^{d} x_{t}=u_{t}, \quad t=1,2, \ldots
$$

where $\mathrm{P}_{\mathrm{iT}}$ are the Chebyshev time polynomials defined by:

$$
P_{0, T}(t)=1, P_{i, T}(t)=\sqrt{2} \cos (i \pi(t-0.5) / T), \quad t=1,2, \ldots, T ; \quad i=1,2, \ldots,
$$

in which $\mathrm{m}$ indicates the degree of non-linearity. Bierens (1997) and Tomasevic and Stanivuk (2009) among others argue that it is possible to approximate highly non-linear trends with rather low degree polynomials. In this context, if $m=0$ the model contains an intercept, if $m=1$ it adds a linear trend, and if $m>1$ the model becomes non-linear, and the higher $m$ is, the less linear the approximated deterministic component becomes. In this study, to allow for some degree of 
generalization, we take $m=3$, and the data will contain non-linear structures if $\theta_{2}$ and/or $\theta_{3}$ are statistically significant. The results for the case of white noise errors are displayed in Table 5 .

\section{[Insert Table 5 about here]}

We observe that non-linearities are present in the five series, and the orders of integration range between 0.56 (for GDP per capita at constant LCU) and 0.93 (for GDP per capita at current USD). The unit root null hypothesis cannot be rejected for three of the series (GDP at current LCU, with $\mathrm{d}=0.91$; GDP at constant $\mathrm{LCU}, \mathrm{d}=0.88$; and GDP per capita at constant $\mathrm{LCU}, \mathrm{D}=0.93$ ), and this hypothesis is rejected in favour of mean reversion $(\mathrm{d}<1)$ for two (GDP at current LCU, $\mathrm{d}=0.57$, and GDP per capita at current USD, with $\mathrm{d}=0.56$ ). Thus, allowing for non-linearities, we observe a reduction in the order of integration of the series and in fact, two of them (namely, GDP at current LCU and GDP per capita at current USD) become mean reverting, with the effect of the shocks disappearing in the long run.

\section{Discussion}

In this section we compare the results displayed above for the Nigerian economy with those obtained in Gil-Alana and Mudida (2018) for the Kenyan economy. In both the Nigerian and Kenyan cases, the series are found to be highly persistent with non-linearities arising in both cases. (See the appendix for the results for the Kenyan economy). ${ }^{2}$ The reasons for persistence and erratic (non-linear) growth are, however, quite different in the Kenyan and Nigerian cases. The Kenyan economy is more diversified relying on agricultural products such as tea, agriculture and horticulture but also on services such as tourism. The Nigerian economy, on the other hand, is

\footnotetext{
2 According to the results displayed in the Appendix, the order of integration of log-(GDP) in Kenya is 1.07 (0.93, $1.28)$ with white noise errors and $0.71(0.54,1.28)$ with autocorrelated disturbances. (Table A2). Imposing non-linear deterministic terms, the values are $0.77(0.54,1.11)$ and $0.18(-0.25,0.76)$ respectively for the two types of errors (Table A4)
} 
heavily dependent on oil which makes up 96 percent of export revenues and attempts at diversification have so far not yielded sufficient fruit. The Nigerian economy has suffered from the Dutch disease and this makes it extremely vulnerable, especially to oil price shocks.

Kenya's economy is characterised by low savings accompanied by poor domestic capital formation, increasing only marginally from $19.4 \%$ in 2007 to $20.1 \%$ in 2011 (Republic of Kenya, 2012). In Nigeria there have been numerous incidences of tremendous growth in the rate of gross fixed capital formation. It was N18.2 billion in 1981 and from 1982 to 1987 it declined until 1988 when it assumed an increasing trend. It rose to N40.1bn in 1990, N141.9bn in 1995, N331.1bn in 2000, N804.4billion in 2005 and N1546.5 billion in 2006. It later increased to N2053 billion in 2008, and N4207.4 billion in 2011 (Kanu, et. al, 2014).

Nigeria's macroeconomic management was much more volatile until the year 2000 under the Obsanjo regime. Nigeria's macroeconomic mismanagement dominated the 1980s and 1990 when downturns in oil prices were offset by heavy external borrowing. Kenya also experienced a period of unstable macroeconomic management, especially during the politically turbulent years of the 1990s. Kenya's economy made a reasonable recovery after 2009, despite the global financial crisis. The years immediately prior to 2014 were years of high growth in Nigeria but this considerably slowed down after the decline in oil prices in 2014.

Despite widely differing economic structures and policy management responses, both Nigeria and Kenya developed deeply extractive institutions in the period after independence. In the Nigerian case, these were closely linked to the political economy of the oil sector and the military dictatorships that characterized the post-independence period. These dictatorships were a prominent feature in Nigeria until the return to civilian rule in the year 2000. In the Kenyan case, the development of extractive institutions were linked to the development of a highly centralised 
state where political power was accompanied by economic accumulation (Mudida, 2009). The trend towards more inclusive institutions began with the inauguration of the new constitution in 2010 which implemented a devolved system of government and was also associated with a deconcentration of executive power (Mudida, 2011). Kenya held its first multi-party elections in 1992 but more inclusive institutions were only established with the promulgation of a new constitution in 2010 and its associated devolved structure.

\section{Concluding Remarks}

This paper has undertaken a comparative analysis between the economic growth series of Nigeria and Kenya, bringing out similarities and differences. The results show high degrees of persistence with estimates of $d$ equal to or higher than 1 in both cases. For Nigeria, while the time trend is found to be statistically significant in all GDP series, it is not in some of the GPD per capita series. This may be due to the problem of income inequality in Nigeria. Non-linearities are found to be present in the series in both the Nigerian and Kenyan cases and are therefore an important characteristic of the time series properties of the data. The two economies, however, have many distinguishing economic features. First, Nigeria is an oil exporting economy while Kenya is an oil importing economy. These oil exports have created great vulnerability in the Nigerian economy to oil price shocks and this might partly explain the erratic nature of growth.

Second, The Kenyan economy, on the other hand, is more diverse in terms of economic sectors although with a large informal sector. Both economies, however, were characterized by the development of extractive institutions in the post-independence period where elites established control over a considerable proportion of the economy. These extractive institutions, however, developed in different ways; being associated with the political economy of oil and military 
dictatorships in Nigeria while they were associated with the development of a highly centralized and non-inclusive one party state regime in Kenya soon after independence. The various analyses in this work are indicative of how these two large economies in distinct regions of Africa have followed different but in some respects similar paths toward economic growth since independence. 


\section{References}

Abbritti, M., L.A. Gil-Alana, Y. Lovcha and A. Moreno (2016) Term Structure Persistence, Journal of Financial Econometrics, 14 (2), 331-352.

Agu, U., \& Evoh, C. J. (2011). Macroeconomic policy for full and productive and decent employment for all: The case of Nigeria (No. 994672123402676). International Labour Organization.

Akinkunmi, M. A. (2017). Nigeria's economic growth: Past, Present and Determinants. Journal of Economics and Development Studies, 5(2), 31-46.

Awe, O. O., Crandell, I., \& Adepoju, A. A. (2015). A Time Varying Parameter State-Space Model for Analyzing Money Supply-Economic Growth Nexus. Journal of Statistical and Econometric Methods, 4(1), 73-95.

Awe, O. O., Akinlana, D. M., Yaya, O. S., \& Aromolaran, O. (2018). Time Series Analysis of the Behaviour of Import and Export of Agricultural and Non-Agricultural Goods in West Africa: A Case Study of Nigeria. Agris On-Line Papers in Economics \& Informatics, 10(2), 15-22.

Baillie, R.T. (1996). Long memory processes and fractional integration in econometrics. Journal of Econometrics, 73, 1, 5-59.

Bierens H.J. (1997). Testing the unit root with drift hypothesis against nonlinear trend stationarity with an application to the US price level and interest rate. Journal of Econometrics, 81: 29-64.

Bloomfield, P. (1973) An exponential model in the spectrum of a scalar time series, Biometrika, 60, 217-226.

Edo, S. E. (1995). An estimation of a model of long-term securities investment in Nigeria. Nigeria Economic and Financial Review, 12, 45-53.

Edo, S. E. (2002). The external debt problem in Africa: A comparative study of Nigeria and Morocco. African Development Review, 14(2), 221-236.

Farole T. and M. Mukhim (2013). Manufacturing Export Competitiveness in Kenya : Policy Note. Washington, DC: World Bank Group, Report No. ACS6849.

Gil-Alana, L.A. and Hualde, J. (2009) Fractional Integration and Cointegration: An Overview with an Empirical Application, The Palgrave Handbook of Applied Econometrics, 2, 434-472.

Gil-Alana, L.A. and Moreno, A. (2012), Uncovering the term premium, Journal of Banking and Finance 36, 4, 1181-1193. 
Gil-Alana, L.A. and R. Mudida (2018), The growth rate series in Kenya. Evidence of nonlinearities and factors behind the slow growth, International Journal of Finance and Economics 23, 2, 111121.

Gil-Alana, L.A and Robinson, P.M. (1997), Testing of unit roots and other nonstationary hypotheses in macroeconomic time series, Journal of Econometrics 80, 241-268.

Granger, C.W.J. (1980) Long Memory Relationships and the Aggregation of Dynamic Models, Journal of Econometrics, 14, 227-238.

Granger, C.W.J. (1981), Some properties of time series data and their use in econometric model specification, Journal of Econometrics 16, 121-130.

Granger, C.W.J. and R. Joyeux, (1980), An introduction to long memory time series models and fractional differencing, Journal of Time Series Analysis 1, 15-39.

Hosking, J.R.M. (1981), Fractional differencing, Biometrika 68, 165-176.

Institute of Economic Affairs (2012), Informal Sector and Taxation in Kenya, Issue No. 29, September

Kanu, S.I., B.A Ozurumba and F.A. Anyanwu (2014), Capital expenditures and gross fixed capital Formation in Nigeria, Journal of Economics and Sustainable Development, The International Institute for Sciene, Technology and Education, IISTE.

Mayoral, L. (2006). Further Evidence on the Statistical Properties of Real GNP. Oxford Bulletin of Economics and Statistics, 68, 901-920.

Michelacci, C. and P. Zaffaroni, (2000), (Fractional) Beta convergence, Journal of Monetary Economics 45, 2129-153.

Mendi, P. and R. Mudida (2018), "The effect on Innovation of Beginning Informal: Empirical Evidence from Kenya," Technology Forecasting and Social Change, Vol. 131, June 2018, pp. 326-335.

Mudida, R. (2009), entitled "The Erosion of Constitutionalism and Underdevelopment: The Kenyan Experience" Eastern Africa Law Review: A Journal of Law and Development, Vols. 3540.

Mudida, R. (2011), "Effective Institutions as the Foundation of Development: A Conceptual and Empirical Discourse" in D. Lutz, P.M. Shimiyu and G. Osengo (eds) Rethinking Integral Development in Africa Nairobi: Consolata Institute of Philosophy Press.

Mudida, R. (2015). Structural Sources of Constitutional Conflicts in Kenya. Saarbrucken, Scholar's Press, 2015. 
Republic of Kenya (2012). Kenya Economic Survey, Kenya National Bureau of Statistics. Republic of Kenya (2018). Kenya Economic Survey, Kenya National Bureau of Statistics.

Tomasevic N.M., Stanivuk T (2009). Regression Analysis and aproximation by means of Chebyshev Polynomial. Informatologia, 42(3): 166-172.

World Bank, 2016, Washington, D.C., World Bank Publications. 
Table 1: Estimates of $d$ under no autocorrelation (white noise)

\begin{tabular}{|c|c|c|c|}
\hline & No regressors & An intercept & A linear time trend \\
\hline GDP constant LCU & $0.93 \quad(0.77,1.17)$ & $1.19(1.00,1.53)$ & $1.20(1.00,1.53)$ \\
\hline GDP current LCU & $0.91 \quad(0.73,1.15)$ & $1.09(0.98,1.32)$ & $1.11(0.94,1.35)$ \\
\hline GDP current USD & $0.93 \quad(0.76,1.15)$ & $1.03(0.90,1.23)$ & $1.03(0.88,1.25)$ \\
\hline CAP constant LCU & $0.93 \quad(0.77,1.17)$ & $1.20 \quad(1.00,1.54)$ & $1.20(1.00,1.54)$ \\
\hline CAP current USD & $0.93 \quad(0.79,1.14)$ & $1.02(0.88,1.23)$ & $1.02(0.88,1.23)$ \\
\hline
\end{tabular}

In bold, the selected models according to the deterministic terms.

Table 2: Estimated coefficients in the selected models in Table 1

\begin{tabular}{|c|cc|c|c|}
\hline & \multicolumn{2}{|c|}{$\mathrm{d}(95 \%$ band) } & Intercept (t-value) & Time trend (t-value) \\
\hline GDP constant LCU & $1.20(1.00,1.53)$ & $29.7764(399.60)$ & $0.0361 \quad(1.75)$ \\
\hline GDP current LCU & $1.11(0.94,1.35)$ & $21.6643(119.66)$ & $0.1810(5.03)$ \\
\hline Dir GDP current & $1.03(0.88,1.25)$ & $22.0766(92.91)$ & $0.0813(2.31)$ \\
\hline \hline CAP constant LCU & $1.20(1.00,1.54)$ & $12.1812(165.59)$ & ----- \\
\hline CAP current USD & 1.02 & $(0.88,1.23)$ & $4.4731(18.84)$ & $0.0610 \quad(1.79)$ \\
\hline
\end{tabular}


Table 3: Estimates of $\mathbf{d}$ with autocorrelation (Bloomfield)

\begin{tabular}{|c|cc|cc|cc|}
\hline & \multicolumn{2}{|c|}{ No regressors } & \multicolumn{2}{|c|}{ An intercept } & \multicolumn{2}{c|}{ A linear time trend } \\
\hline GDP constant LCU & 0.83 & $(0.49,1.24)$ & 0.79 & $(0.49,1.14)$ & $\mathbf{0 . 8 0}(\mathbf{0 . 4 8}, \mathbf{1 . 1 6})$ \\
\hline GDP current LCU & 0.77 & $(0.34,1.21)$ & 1.01 & $(0.88,1.27)$ & $\mathbf{0 . 9 8}$ & $(\mathbf{0 . 6 5}, \mathbf{1 . 3 6})$ \\
\hline GDP current USD & 0.83 & $(0.49,1.23)$ & 1.04 & $(0.73,1.45)$ & $\mathbf{1 . 0 4}(\mathbf{0 . 7 5}, \mathbf{1 . 4 8})$ \\
\hline \hline CAP constant LCU & 0.85 & $(0.53,1.25)$ & 0.77 & $(0.39,1.16)$ & $\mathbf{0 . 7 9}$ & $(\mathbf{0 . 4 9}, \mathbf{1 . 1 6})$ \\
\hline CAP current USD & 0.94 & $(0.68,1.29)$ & $\mathbf{1 . 0 6}(\mathbf{0 . 7 2}, \mathbf{1 . 4 3})$ & $1.06(0.78,1.46)$ \\
\hline
\end{tabular}

In bold, the selected models according to the deterministic terms.

Table 4: Estimated coefficients in the selected models in Table 3

\begin{tabular}{|c|cc|c|c|}
\hline & \multicolumn{2}{|c|}{$\mathrm{d}(95 \%$ band $)$} & Intercept $(\mathrm{t}-\mathrm{value})$ & Time trend (t-value) \\
\hline GDP constant LCU & 0.80 & $(0.48,1.16)$ & $29.7646(418.86)$ & $0.0360 \quad(7.58)$ \\
\hline GDP current LCU & 0.98 & $(0.65,1.36)$ & $21.6274(118.96)$ & $0.1871 \quad(8.35)$ \\
\hline GDP current USD & 1.04 & $(0.75,1.48)$ & $22.0769(92.97)$ & $0.0812(2.23)$ \\
\hline \hline CAP constant LCU & 0.79 & $(0.49,1.16)$ & $12.1681(171.71)$ & $0.0106(2.31)$ \\
\hline CAP current USD & 1.06 & $(0.72,1.43)$ & $4.5209(19.27)$ & ----- \\
\hline
\end{tabular}

Table 5: Estimated values in the nonlinear framework given by (3)

\begin{tabular}{|c|c|c|c|c|c|}
\hline Series & $\mathrm{d}$ & $\theta_{0}$ & $\theta_{1}$ & $\theta_{2}$ & $\theta_{3}$ \\
\hline GDP constant & 0.91 & $\mathbf{2 6 . 4 6 6 7}$ & $\mathbf{- 3 . 4 1 1 6}$ & $\mathbf{0 . 3 4 2 2}$ & $\mathbf{- 0 . 2 1 2 4}$ \\
LCU & $(0.67,1.25)$ & $\mathbf{( 5 0 . 7 5 )}$ & $\mathbf{( - 1 1 . 3 8 )}$ & $\mathbf{( 2 . 0 6 )}$ & $\mathbf{( - 1 . 9 4 )}$ \\
\hline GDP current & 0.57 & $\mathbf{2 4 3 4 9 6 7}$ & $\mathbf{- 1 . 1 1 6 5}$ & $\mathbf{0 . 1 5 7 3}$ & $\mathbf{- 0 . 6 2 0 0}$ \\
LCU & $(0.25,0.93)$ & $\mathbf{( 1 2 0 . 8 7 )}$ & $\mathbf{( - 9 . 6 1 )}$ & $\mathbf{( 1 . 7 7 )}$ & $\mathbf{( - 8 . 6 4 )}$ \\
\hline GDP current & 0.88 & $\mathbf{3 0 . 6 9 4 4}$ & $\mathbf{- 0 . 5 1 2 8}$ & $\mathbf{0 . 1 0 5 2}$ & $\mathbf{- 0 . 2 1 9 2}$ \\
USD & $(0.52,1.38)$ & $\mathbf{( 1 5 8 . 2 0})$ & $\mathbf{( - 4 . 6 3 )}$ & $\mathbf{( 1 . 6 6 )}$ & $\mathbf{( - 4 . 9 1 )}$ \\
\hline \hline CAP constant & 0.93 & $\mathbf{1 2 . 4 0 5 8}$ & -8.8463 & $\mathbf{0 . 1 0 3 4}$ & $\mathbf{- 0 . 1 7 4 9}$ \\
LCU & $(0.57,1.40)$ & $\mathbf{( 5 3 . 7 2 )}$ & $\mathbf{( - 0 . 6 6 )}$ & $\mathbf{( 1 . 7 3 )}$ & $\mathbf{( - 3 . 5 2 )}$ \\
\hline CAP current & 0.56 & $\mathbf{6 . 0 3 5 4}$ & $\mathbf{- 0 . 6 7 3 0}$ & $\mathbf{0 . 1 4 6 0}$ & $\mathbf{- 0 . 5 9 1 0}$ \\
USD & $(0.28,0.91)$ & $\mathbf{( 3 1 . 1 2 )}$ & $\mathbf{( - 5 . 9 9 )}$ & $\mathbf{( 1 . 6 9 )}$ & $\mathbf{( - 8 . 4 3 )}$ \\
\hline
\end{tabular}

In bold, the significant coefficients for the deterministic terms at the 5\% level. 


\section{Appendix: Results for Kenya}

Table 1: Estimates of $d$ and $95 \%$ confidence intervals

\begin{tabular}{|c|c|c|c|}
\hline & No regressors & An intercept & A linear time trend \\
\hline White noise & $0.09 \quad(-0.11,0.34)$ & $0.07 \quad(-0.07,0.28)$ & $-0.01 \quad(-0.19,0.27)$ \\
\hline Autocorrelation & $-0.06 \quad(-0.43,0.47)$ & $-0.02 \quad(-0.25,0.31)$ & $-0.29 \quad(-0.46,0.28)$ \\
\hline
\end{tabular}

In bold, the selected model according to the deterministic terms.

Table A2: Estimated coefficients in the models presented in Table 1

\begin{tabular}{|c|cc|c|c|c|}
\hline & \multicolumn{2}{|c|}{$\mathrm{d}$ in growth $\mathrm{rt}}$. & $\mathrm{d}$ in output & Intercept & Time trend \\
\hline White noise & $0.07 \quad(-0.07,0.28)$ & $1.07 \quad(0.93,1.28)$ & $\begin{array}{c}4.4827 \\
(5.800)\end{array}$ & $\mathrm{xxx}$ \\
\hline Autocorrelation & $-0.29 \quad(-0.46,0.28)$ & $0.71 \quad(0.54,1.28)$ & $\begin{array}{c}(6.1241 \\
(11.237)\end{array}$ & $\begin{array}{c}-0.0575 \\
(-3.103)\end{array}$ \\
\hline
\end{tabular}

Table A3: Estimates of $d$ and $95 \%$ confidence intervals in the non-linear cases

\begin{tabular}{|c|rcc|cc|}
\hline & \multicolumn{3}{|c|}{$\mathrm{m}=2$} & \multicolumn{2}{c|}{$\mathrm{m}=3$} \\
\hline White noise & -0.04 & $(-0.23$, & $0.25)$ & $\mathbf{- 0 . 2 3}$ & $\mathbf{( - 0 . 4 6 ,}, \mathbf{0 . 1 1})$ \\
\hline Autocorrelation & -0.39 & $(-0.78,0.17)$ & $\mathbf{- 0 . 8 2}$ & $\mathbf{( - 1 . 2 5 ,}-\mathbf{- 0 . 2 4})$ \\
\hline
\end{tabular}

In bold, the selected models according to the deterministic terms.

Table A4: Estimated coefficients in the models presented in Table 3

\begin{tabular}{|c|c|c|c|c|c|c|}
\hline & $\mathrm{d}$ in growth $\mathrm{rt}$ & $\mathrm{d}$ in output & $\begin{array}{c}\theta_{1} \\
\text { (t-value) }\end{array}$ & $\begin{array}{c}\theta_{2} \\
\text { (t-value) }\end{array}$ & $\begin{array}{c}\theta_{3} \\
\text { (t-value) }\end{array}$ & $\begin{array}{c}\theta_{4} \\
\text { (t-value) }\end{array}$ \\
\hline White noise & $\begin{array}{c}-0.23 \\
(-0.46, \quad 0.11)\end{array}$ & $\begin{array}{c}0.77 \\
(0.54,1.11)\end{array}$ & $\begin{array}{c}-4.540 \\
(18.600)\end{array}$ & $\begin{array}{c}\mathbf{0 . 8 8 0} \\
(2.752)\end{array}$ & $\begin{array}{c}0.221 \\
(2.626)\end{array}$ & $\begin{array}{c}-1.272 \\
(-3.346)\end{array}$ \\
\hline Autocorrelation & $\begin{array}{c}-0.82 \\
(-1.25,-0.24)\end{array}$ & $\begin{array}{c}0.18 \\
(-0.25,-0.76)\end{array}$ & $\begin{array}{c}-4.555 \\
(75.534)\end{array}$ & $\begin{array}{c}\mathbf{0 . 8 0 3} \\
(7.805)\end{array}$ & $\begin{array}{c}0.254 \\
(1.882)\end{array}$ & $\begin{array}{c}-1.337 \\
(-7.784)\end{array}$ \\
\hline
\end{tabular}

In bold, significant coefficients at the $5 \%$ level. 